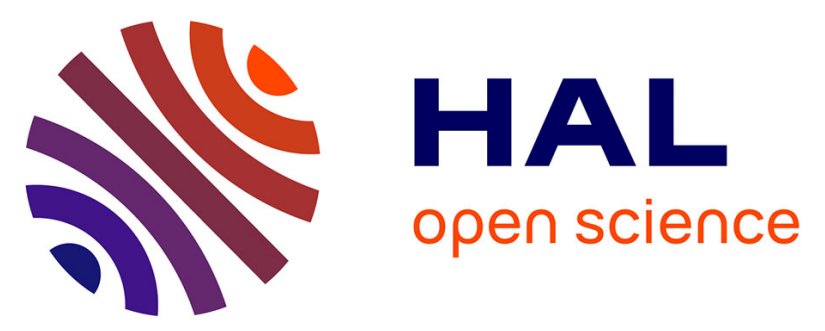

\title{
Feminist Technoscience as a Resource for Working with Science Practices, a Critical Approach, and Gender Equality in Swedish Higher IT Educations
}

\author{
Johanna Sefyrin, Pirjo Elovaara, Christina Mörtberg
}

\section{To cite this version:}

Johanna Sefyrin, Pirjo Elovaara, Christina Mörtberg. Feminist Technoscience as a Resource for Working with Science Practices, a Critical Approach, and Gender Equality in Swedish Higher IT Educations. 13th IFIP International Conference on Human Choice and Computers (HCC13), Sep 2018, Poznan, Poland. pp.221-231, 10.1007/978-3-319-99605-9_16 . hal-02001957

\section{HAL Id: hal-02001957 \\ https://hal.inria.fr/hal-02001957}

Submitted on 31 Jan 2019

HAL is a multi-disciplinary open access archive for the deposit and dissemination of scientific research documents, whether they are published or not. The documents may come from teaching and research institutions in France or abroad, or from public or private research centers.
L'archive ouverte pluridisciplinaire HAL, est destinée au dépôt et à la diffusion de documents scientifiques de niveau recherche, publiés ou non, émanant des établissements d'enseignement et de recherche français ou étrangers, des laboratoires publics ou privés. 


\title{
Feminist Technoscience as a Resource for Working with Science Practices, a Critical Approach, and Gender Equality in Swedish Higher IT Educations
}

\author{
Johanna Sefyrin $^{1[0000-0002-9626-6772]}$, Pirjo Elovaara ${ }^{2}$, and Christina Mörtberg ${ }^{3}$ \\ ${ }^{1}$ Linköping University, 58183 Linköping, Sweden. \\ johanna.sefyrin@liu.se \\ ${ }^{2}$ Blekinge Institute of Technology, 37179 Karlskrona, \\ ${ }^{3}$ Linnæus University, 35195 Växjö
}

\begin{abstract}
Science is according to the Swedish legislation for higher education (Högskoleförordningen) a central quality aim for higher educations. In the Swedish Higher Education Authority's (UKÄ) new quality assurance system, the integration of gender equality is one of several quality aspects that are being measured. This paper concerns a planned study with the aim to explore how feminist technoscience can contribute to challenging existing science practices, and a critical approach, while at the same time work as a theoretical resource for the integration of gender equality in Swedish higher IT educations. Feminist technoscience makes possible critical questions about scientific practices in both educational contexts and in work life, about researchers' positioning, about consequences, and about power issues. Posing such questions is central in IT educations, since we live in a society in which digital technologies increasingly constitute preconditions for a working reality, and both reproduce existing structures and form new patterns. In this reality it is central to ask whether current science practices are enough, and how feminist technoscience can make a difference, in those educations that produce the IT experts of the tomorrow. The study will be conducted as a qualitative field study with a focus on how teachers and students in Swedish higher IT educations practice science and a critical approach, and feminist technoscience in their educations.
\end{abstract}

Keywords: Science Practices, Critical Approach, Swedish Higher IT Education, Feminist Technoscience.

\section{Introduction}

This paper concerns a planned study in which we plan to explore how feminist technoscience can contribute to challenging existing science practices, and a critical approach, while at the same time work as a theoretical resource for the integration of gender equality in Swedish higher IT educations in a broad sense - information systems/informatics, engineering with a focus on computers and IT, and media and digital technologies programs. According to the Swedish Higher Education Ordinance (Högskoleförordningen), science and a critical approach are central quality aims and 
an important part of the educational content on a higher educational level. Furthermore, in the Swedish Higher Education Authority's (UKÄ) new quality assurance system for higher education, gender equality is one of several quality aspects that are being measured. In the planned study we are interested in exploring questions of what science means in Swedish higher IT educations, how it is practiced, and if the current science practices in Swedish IT educations are enough to prepare the students for the challenges they will face as practitioners in a society which is increasingly digitalized in complex ways, and in which the digital and the social are increasingly, and intimately, entangled. In these explorations we will use feminist technoscience as a resource that can provide guidance for how to make a difference. A central concern in feminist technoscience is knowledge processes, in terms of the development of scientific knowledge, but also in terms of the design of technologies, and the implicit and explicit knowledge of organizational and social structures, practices and hierarchies that are inscribed into technologies [27], [49]. Researchers within the field have shown how the development of knowledge is intimately related to how the involved actors (researchers, designers, users etc.) are implicated in social and material relations, including those of gender, ethnicity, class and sexuality [18], [30], [42], [49], [52]. Feminist technoscience is inspired by constructionist approaches, and a central point of departure is that neither technology nor gender is understood as fixed or given. Rather, technology is understood as "contingently stabilized and contestable" [49, p. 8], and in a similar way gender is understood as a performance, or a social achievement [ibid.]. Feminist technoscience focus on gender equality - the social, economic and political relations between women and men in the production, design and use of technologies [ibid.], as well as the performance of gender. Gender and gender equality are related, and research in the field shows that femininity and masculinity are performed not only in relation to each other, but also in relation to technologies [ibid.]. Hence a central focus is on how gender and technology are mutually shaped in processes of development of scientific knowledge, and of design and use of technologies, in which neither are understood as fixed or given in advance [ibid.]. While the research field addresses a range of technologies, here we are interested in the technoscience processes that concerns digital technologies, both in terms of development of scientific knowledge, and processes of design and use.

Feminist science and technoscience scholars have been studying technoscience use, design and development practices, as well as the consequences of these practices during several decades [10], [23, 24], [20], [4], and have a lot to contribute with to more mainstream approaches, which have focused on other aspects of science practices, both in terms of how to understand and theorize these problems, but also for how they can be dealt with. Feminist technoscience constitutes a ground for posing critical questions about scientific practices, about researchers' positioning, about consequences of these practices for different actors, and about power issues related to knowledge making and scientific practices. A central point of departure for feminist technoscience is that science and technology are entangled with social interests, and that the involved researchers and knowledge developers must be understood as politically and ethically responsible for the practices and interventions that research may give rise to [52]. 
So, the aim with this study is to explore how feminist technoscience can contribute to challenging existing science practices, and a critical approach, while at the same time work as a theoretical resource for the integration of gender equality in Swedish higher IT educations in a broad sense. Exactly what the term science practices mean differs between disciplines, but our view of scientific practices is based on the use of this term in the research field of feminist technoscience, in which scientific practices are much more far reaching than those who take place in laboratories [26], [28]. The main research question is: How can feminist technoscience be a part of scientific practices and a critical approach in Swedish higher IT educations? This overarching question is broken down into three sub-questions: (1) Which are the scientific points of departure in Swedish higher IT educations? (2) Which are the possibilities or hindrances for an integration of gender equality in Swedish higher IT educations? And (3) How can feminist technoscience make a difference in the work with scientific practices and gender equality integration in Swedish higher IT educations?

\section{Background}

The background for our interest in gender equality and its relations to digital technologies is that these technologies are becoming more and more ubiquitous, and increasingly affect all the fine-grained parts of current societies and individuals' lives, and while they solve some of the existing problems, at the same time they give rise to new challenges [45], [44]. Some interpret this development as a fourth industrial revolution [46] (World Economic Forum, 2016), or as "a second machine age" [9], and then refer to how digital technologies such as 3D-printing, big data, artificial intelligence, robotics and automation, in combination with demographic changes, urbanization and globalization, are merged and amplify each other, and are expected to affect all parts of society in a disruptive way [45]. Be this a revolution or not, but it indicates a world of increasing complexity, in which digital technologies and relations play an important part, both in terms of constituting complexity, and in terms of expectations to contribute to solutions. Researchers have underscored that technologies are formative and do not only mirror an existing social order, but are designed in entangled relations of various agencies, and they reproduce the existing social, economic, cultural and political relations - including gender, ethnicity and class [27], [48, 49], [7]. Consequently technologies make possible some ways of acting, being, and living, and make other activities, and ways of being and living harder [29], [52], [49], [37], something which contributes to making some identities, positions and parts of the world visible, while some are made invisible [8], [29]. Hence digital technologies must be understood as inextricable from other relations, practices, and structures of societies [52], [7], [49].

The actors involved in designing and developing digital technologies do this in a world that is increasingly complex, and in which these technologies are more and more entangled with other parts of societies, including gender relations. Insights from research in feminist technoscience underscores that the processes of scientific knowledge, as well as design and development of technologies, are intimately inter- 
twined with social issues - the social, the technological and the scientific are understood as knitted together in a seamless web of relations [49]. Researchers in the field also explore issues concerning consequences of technoscience practices, and argue that researchers, designers and developers must be understood as responsible - and accountable [3] - for the consequences of the technologies they contribute to shaping [52]. This requires that researchers and practitioners need to be prepared for this, in terms of for instance an ability to critically reflect on digital technologies' reproduction of problematic power relations and structures, their entanglement in power relations and their consequences for different actors - what the technologies do. These designers and developers - IT experts who often have a formal university degree of some sort, are shaped during their education. These higher IT educations prepare the students - who are the IT experts and decision makers of tomorrow - for professional practice. During higher education the disciplinary knowledge and traditions concerning which problems are interesting and possible to solve, what is doable, how the subject area is defined, and the view of what approaches and methods are useful in a specific situation, are communicated [25], [6], [36].

From the point of view of feminist technoscience, the design and production of science and technology cannot be distinguished from the networks, structures and practices in which it is enmeshed, so from this perspective, the issue of how to better prepare students in IT educations for their professional activities in an increasingly complex world, is all a matter of technoscience practices [26], [19, 20], [4], [52]. It is a matter of how the design of technosciences are entangled in existing power relations, practices and structures, about the positioning of the researchers, and of the need for researchers to be aware of their responsibility of the possible consequences of technoscience practices and interventions. In this landscape of increasing digital complexity constituted of what Sørensen [45] discusses as combinations of digitalization, distribution and scale, we are faced with new challenges in the crossroads between disciplines. These questions concern issues of who is included and excluded in the design and use of digital technologies [14], [35], the unintended inscription of gender stereotypes into seemingly gender neutral digital technologies [34], computer ethics [1], care in technoscience practices [13], digital technologies in relation to environmental sustainability [31], and to the Anthropocene [46], just to name a few. This necessitates the possibility to ask questions that might require wider approaches than are currently possible within disciplinary boundaries, but that rather require multidisciplinary approaches [45], [50], [2]. In this situation we view feminist technoscience - with its focus on entangled practices in which humans are deeply and ontologically related with the social and material world, and on the gendered and ethical issues that arise in these practices [4], [41] - as a resource for asking complex but pressing questions.

\section{Theoretical Framework}

For the study we will take as our analytical point of departure feminist technoscience [20], [52], [49], [38]. Feminist technoscience can be understood as a knowledge field 
that is part of the larger field of feminist studies, and borrow theoretical inspiration from feminist science scholars such as Donna Haraway [20, 22], Sandra Harding [23] and Karen Barad [3]. Åsberg and Lykke [52, p. 299] write that

"Feminist technoscience studies is a relentlessly transdisciplinary field if research which emerged out of decades of feminist critiques. These critiques have revealed the ways in which gender, in its intersections with other sociocultural power differentials and identity markers, is entangled in natural, medical and technical sciences as well as in the sociotechnical networks and practices of a globalized world".

Feminist technoscience concerns the application of feminist science critique and analysis on scientific and other knowledge practices in order to explore the relations between feminism and science, and what they can learn from each other [52]. Moreover, technology and gender are viewed as mutually shaped, that is, technology is both a source and a consequence of gender relations [ibid.] (ibid.). Latour's [27] statement that "technology is society made durable" underscores how existing sociopolitical hierarchies and relations are inscribed into technologies, which then contribute to the (re)production of for instance gender relations. An important point of departure is that also so called pure basic science is entangled in social interests, and that the involved researchers and knowledge developers must be understood as politically and ethically responsible for the practices and interventions that research may give rise to [52]. Feminist technoscience is a critical approach, and underscore that technosciences are often used in order to advance the interests of capitalist interests [ibid.], but an important focus is that it does not have to be this way. Feminist technoscience concerns both technological and scientific (technoscience) practices in general, and analyze the design and development of technological artefacts and systems in the same way as science practices are analyzed.

One central issue concerns how researchers' and other actors' situatedness affect their knowledge practices [19]. de la Bellacasa writes "That knowledge is situated means that knowing and thinking are inconceivable without a multitude of relations that also make possible the worlds we think with. The premise to my argument can therefore be formulated as follows: relations of thinking and knowing require care" [13, p. 198]. Another focus is how power relations affect who is included and who is not in technoscience practices [24], [14], how technosciences such as digital technologies contribute to both the reproduction of problematic social, economic and material structures, and to the destabilization of these [27], [8], problematic categorizations and representational practices [8], [3], [39], and power/knowledge in technoscience practices [17]. Feminist technosciences underscore that gender science is not only about relations between women and men, but also about understanding agency, bodies, rationality and the boundary making between e.g. nature and culture in technoscience practices [52].

The theoretical discussions in the field of feminist technoscience during the last years have centered on a number of 'turns' such as the posthumanist, materialist and ontological turn [52], and also the term Anthropocene is discussed [46]. These ideas 
have been used by a number of researchers in order to explore how gender and other aspects of reality are inscribed into information technology [5], [40], the accountability of designers, and strategies for designing without inscribing fixed or naturalized notions of gender into designs [47], entanglements of humans and machines [41], [16], sociomaterial relations in participatory design methods [15], gendered discourses in IT educations [12], and legal, ethical, and moral questions that surround security technologies [43]. These researchers focus on how, in design and use practices, humans are entangled with materialities (technological and other), how sociopolitical realities such as gender, ethnicity and class are inscribed into technologies which in turn reproduces these realities. These researchers explore how this takes place, the consequences of this, and on developing possible alternatives that are less problematic. The works of these researchers are often published in journals with an interdisciplinary scope, rather than in mainstream disciplinary journals, something which probably contributes to the fact that this knowledge is relatively unknown in related research fields such as in the more mainstream information systems (IS) field. In mainstream IS journals some of the ideas of feminist technoscience is discussed under the umbrella term of sociomaterialities [e.g. 33], [11], [32]. This research is based primarily on socio-technical systems theory, actor network theory, and practice theory [11], and less on feminist technoscience, but the works of Karen Barad [3, 4] is nevertheless central. Consequently these discussions mostly go into the posthumanist ideas of feminist technoscience, and touch upon the consequences of this for information systems design, but do not go into the feminist concerns that are in focus in feminist technoscience. Here we argue that the feminist focus on who is involved in technoscience practices, and how the consequences of technoscience practices affect different bodies differently, would add important insights also in related disciplines.

For the planned research application we argue that the area of feminist technoscience is relevant for contributing to scientific practices and gender equality in IT educations, as digital technologies today constitute an increasingly integral part of society, both in terms of infrastructural preconditions for societal functions and services, and in terms of how social development is highly affected by the innovation and design of digital technologies. In several respects these technologies contribute to solving existing problems, and to a better life for many individuals, but they also reproduce problematic structures, and cause new problems and challenges. This points to the importance of working with issues of scientific practices concerning those issues that are in focus in feminist technoscience such as technological consequences, the responsibility and accountability of the designers of digital technologies, and of the relations of gender, sexuality, ethnicity and power in which design practices are entangled.

\section{Methodological Approach}

The planned study will be conducted as a qualitative field study, in which we study how teachers and students in Swedish higher IT educations understand and work with scientific practices and a critical approach, and how they work with gender issues - if 
this is done in terms of gender equality or if it is also done in terms of gender science as a ground for scientific practices, and if so, how this is done. The field study will be conducted through interviews, but also through the study of documents such as course syllabuses, course literature lists and other documents that describe how the teaching in those areas is planned and conducted. We have as our starting point for the practical implementation of the study the Swedish Information Systems Academy (SISA: http://sisa-net.se). We are also part of a recently initiated Swedish network for feminist technoscience, through which we will be able to find more colleagues with this kind of competence. These colleagues work with higher IT educations such as information systems/informatics, engineering with a focus on IT, and media and digital technologies programs, programs located at both philosophical and technical faculties.

Our plan is not to evaluate whether representatives of Swedish IT educations work with gender science as scientific practices, but rather to explore how this is currently done, ideas for how it can be done, and how feminist technoscience can make a difference compared to more mainstream approaches to science. This exploration of current competencies and practices in the area will be combined with the study of relevant research literature. Since the involved researchers work with feminist technoscience, this will constitute an analytical point of departure, with the aim of identifying different ways of working with feminist technoscience in higher IT educations, apart from working with gender equality and the recruitment of women to male dominated technical educations.

Our plan is to start the work by exploring how scientific practices and a critical approach is understood and practiced in Swedish higher IT educations, through collecting central policy documents - both national and local - and through interviewing teachers and students at some of these educations. Then we will proceed by mapping the Swedish higher IT educations which in some way work with gender and feminist technoscience, and interview teachers and students in those educations with a focus on how this is done and what it contributes with. Through this we will obtain information about how working with feminist technoscience in higher IT educations differ from, and might contribute to the work with scientific practices and a critical approach from a more traditional perspective.

Table 1. Project plan

\begin{tabular}{|l|l|l|}
\hline Year & Activities/Tasks & Outcomes/Milestones \\
\hline 2019 & a) Initial literature study. & M1: Initial overview of relevant re- \\
& $\begin{array}{l}\text { Duration: January - March } \\
\text { b) Map Swedish higher IT educations }\end{array}$ & \\
& $\begin{array}{l}\text { Duration: March } \\
\text { c) Take part of relevant national and } \\
\text { local steering documents concerning } \\
\text { scientific practices and a critical ap- } \\
\text { proach. }\end{array}$ & $\begin{array}{l}\text { M1: In studitial overview of how scientific } \\
\text { practices is defined in documents }\end{array}$ \\
$\begin{array}{l}\text { Duration: Mid January - May } \\
\text { d) Planning of the empirical studies and } \\
\text { recruitment of participants }\end{array}$ & M3: Acceptance to participate in the \\
\hline
\end{tabular}




\begin{tabular}{|c|c|c|}
\hline & $\begin{array}{l}\text { Duration: June } \\
\text { d) Carry through a number of inter- } \\
\text { views. } \\
\text { Duration: June - December } \\
\text { e) Project management : plan regular } \\
\text { meetings, necessary reports, follow up } \\
\text { budget, recruit a person for the tran- } \\
\text { scriptions } \\
\text { Duration: January - December }\end{array}$ & $\begin{array}{l}\text { study } \\
\text { M4: Empirical material collected } \\
\text { M5: Disseminate the follow-up to the } \\
\text { project and acccounting administrator } \\
\text { M6: Any requested reports have been } \\
\text { turned in to the department and research } \\
\text { council }\end{array}$ \\
\hline 202 & $\begin{array}{l}\text { f) Transcribe and compile the gathered } \\
\text { material } \\
\text { Duration: January - March } \\
\text { h) Map IT educations which work with } \\
\text { gender studies/feminist technoscience } \\
\text { Duration: March } \\
\text { i) Planning of the empirical studies and } \\
\text { recruitment of participants } \\
\text { Duration: March } \\
\text { j) Carry through interviews with a focus } \\
\text { on how gender studies/feminist techno- } \\
\text { science is practiced. } \\
\text { Duration: April - October } \\
\text { k) Transcribe and compile the gathered } \\
\text { material } \\
\text { Duration: mid January - April } \\
\text { 1) Project management: necessary re- } \\
\text { ports to department and the research } \\
\text { council, follow up budget } \\
\text { Duration: January - December }\end{array}$ & $\begin{array}{l}\text { M10: Empirical material collected } \\
\text { M11: Digitalisation of the collected } \\
\text { material } \\
\text { M12: Disseminate the follow-up to the } \\
\text { project and accounting administrator at } \\
\text { the department } \\
\text { M13: Any requested reports have been } \\
\text { turned in }\end{array}$ \\
\hline 202 & $\begin{array}{l}\text { m) Analysis and synthesis of research } \\
\text { material } \\
\text { Duration: January - June } \\
\text { n) Dissemination: } \\
\text { na) To scholars: Journals and confer- } \\
\text { ence papers } \\
\text { Duration: June - December } \\
\text { nb) To research participants and organi- } \\
\text { sations } \\
\text { nc) To teachers: Knowledge support } \\
\text { Duration: May - August } \\
\text { o) Project management: plan and facili- } \\
\text { tate reporting } \\
\text { Duration: January - December }\end{array}$ & $\begin{array}{l}\text { M13: Conceptualisation scientific } \\
\text { practices and a critical approach in } \\
\text { combination with FTS } \\
\text { M14: Journals: Information, } \\
\text { Technology \& People, and/or Science, } \\
\text { Technology \& Human Values, NORA - } \\
\text { Nordic Journal of Feminist and Gender } \\
\text { Research, International Journal of } \\
\text { Feminist Technoscience } \\
\text { M16: Popular scientific publication } \\
\text { M17: The report of the project sent to } \\
\text { the research council, report to the de- } \\
\text { partment }\end{array}$ \\
\hline
\end{tabular}

\section{$5 \quad$ Expected Results and Contributions}

We - the researchers who plan this study - position ourselves in the crossroads between feminist technoscience, informatics, information systems (IS), and media technology. As underscored by for instance Walsham [50], who work in the information 
systems (IS) field, this field has traditionally focused on helping organizations to use information and communication technologies more effectively, with the aim to improve organizational effectiveness in capitalist interests. Walsham [ibid.] argue that researchers in the IS field should focus more on how digital technologies can be developed and used in order to contribute to a better world, in a way that also serves other interests than those of efficiency and effectiveness. Ethical, as well as gender issues, related to information systems are not entirely absent to the IS field, but are nevertheless rather marginalized, as discussed by Adam [2]. Feminist technoscience is a research field that focus simultaneously on scientific practices and their embeddedness in social and political relations, and on the practical, political and ethical consequences of these practices [52]. In this application the significance and planned novelty concerns bringing into the related fields of informatics, information systems and media technology the insights of how gender and knowledge practices are related to both scientific and design practices, knowledge that can also be used in Swedish higher IT educations. These issues are relatively unknown in for instance the field of information systems, and would add significantly to the current discussion both on how the IS field should focus on contributing to a better world, rather than only focus on improving efficiency and effectiveness in capitalist interests [see 50], and the discussion about "sociomaterialities" [e.g. 33], [11], [32] which has introduced the posthumanist ideas embraced by feminist technoscience into the IS field, but which mostly bypasses the feminist concerns. We argue that this discussion would benefit significantly from acknowledging the research that over the years has been done in the field of feminist technoscience, albeit in interdisciplinary journals and conferences rather than in mainstream IS journals, and also acknowledging the full meaning and relevance of the posthumanist ideas now being discussed in the mainstream IS field, that is, of how the entanglement of the social and the material include also the entanglement of sociopolitical relations such as gender, ethnicity and class in the design and use of information systems.

\section{Discussion}

This short paper has presented a planned study with the aim we aim to explore how gender science can contribute to science practices and a critical approach, while at the same time work as a theoretical resource for the integration of gender equality, in Swedish higher IT educations in a broad sense - information systems/informatics, engineering with a focus on computers and IT, and media and digital technologies programs. The most expected result of the study is foremost to bring into the related areas of information systems, informatics, and media technology the insights of feminist technoscience, of how an analytical focus on gendered bodies matter in technoscience practices. 


\section{Acknowledgements}

We would like to thank the reviewers for their constructive feedback and suggestions for how to improve the paper.

\section{References}

1. Adam, Alison. Gender, Ethics and Information Technology. Basingstoke, Palgrave Macmillan (2005).

2. Adam, Alison: IS and its agenda. Journal of Information Technology, 27(2), 102 (2012).

3. Barad, Karen: Posthumanist performativity: Toward an understanding of how matter comes to matter. Signs: Journal of women in culture and society, 28(3), 801-831 (2003).

4. Barad, Karen: Meeting the universe halfway: Quantum physics and the entanglement of matter and meaning. Duke university Press, Princeton (2007).

5. Bath, Corinna. Searching for Methodology. In Waltraud Ernst \& Ilona Horwath (eds.), Gender in Science and Technology, Interdisciplinary Approaches. Pp. 5778 (2013).

6. Berner, Boel: Perpetuum mobile? Teknikens utmaningar och historiens gång. Arkiv Förlag, Lund (1999).

7. Bijker, Wiebe E.: How is technology made?-That is the question!. Cambridge journal of economics, 34(1), 63-76 (2009).

8. Bowker, Geoffrey, \& Star, Susan L.: Sorting things out. Classification and its consequences. The MIT Press, Cambridge \& London (1999).

9. Brynjolfsson, Erik, \& McAfee, Andrew: The second machine age: Work, progress, and prosperity in a time of brilliant technologies. WW Norton \& Company (2014).

10. Butler, Judith: Bodies That Matter. On the Discursive Limits of "Sex". Routledge, New York and London (1993).

11. Cecez-Kecmanovic, D., Galliers, R. D., Henfridsson, O., Newell, S., \& Vidgen, R.. The sociomateriality of information systems: current status, future directions. Mis Quarterly, 38(3), 809-830 (2014).

12. Corneliussen, Hilde: Diskursens makt-individets frihet: Kjønnede posisjoner i diskursen om data (The power of discourse-the freedom of individuals: Gendered positions in the discourse of computing) (Doctoral dissertation, thesis, Dep. of humanistic informatics, University of Bergen) (2002). 
13. de la Bellacasa, Maria Puig. Matters of care in technoscience: Assembling neglected things. Social studies of science, 41(1), 85-106 (2011).

14. Elovaara, Pirjo, Igira, Faraja T. \& Mörtberg, Christina: Whose participation? Whose knowledge? Exploring PD in Tanzania-Zanzibar and Sweden. In Gianni Jacucci \& Finn Kensing (Eds.), Proceedings of the ninth Participatory Design Conference. ACM (2006).

15. Elovaara, Pirjo, \& Mörtberg, Christina. Carthographic mappings: participative methods. In Proceedings of the 11th Biennial Participatory Design Conference (pp. 171-174). ACM (2010).

16. Ernst, Waltraud. Emancipatory interferences with machines?. International Journal of Gender, Science and Technology, 9(2), 178-196 (2017).

17. Finken, Sisse: Methods as technologies for producing knowledge. An encounter with cultural practices - reflections from a field study in a high-tech company. Doctoral dissertation, Roskilde University (2005).

18. Hackett, Edward J., Amsterdamska, Olga, Lynch, Michael, \& Wajcman, Judy: The handbook of science and technology studies. The MIT Press (2008).

19. Haraway, Donna: Situated Knowledges: The Science Question in Feminism and the Privilege of Partial Perspective. In Donna Haraway (Ed.), Simians, Cyborgs, and Women. The Reinvention of Nature (183-201). Routledge, New York (1991).

20. Haraway, Donna: Modest_Witness@Second_Millennium. FemaleMan@_Meets_OncoMouse ${ }^{\mathrm{TM}}$. Feminism and Technoscience. Routledge, New York \& London (1997).

21. Haraway, Donna (Ed.): The Haraway Reader (321-342). Routledge, New York (2004).

22. Haraway, Donna J.. When species meet (Vol. 224). University of Minnesota Press (2008).

23. Harding, Sandra G.: The science question in feminism. Cornell University Press, Ithaca, N.Y (1986).

24. Harding, Sandra: Whose Science? Whose Knowledge? Thinking From Women's Lives. Cornell University Press, Ithaca, N.Y. (1991).

25. Huber, Ludwig: "Disciplinary cultures and social reproduction." European Journal of Education (1990): 241-261 (1990).

26. Latour, Bruno: Science in action: How to follow scientists and engineers through society. Harvard university press, Harvard (1987).

27. Latour, Bruno: Technology is society made durable. The Sociological Review, 38(1_suppl), 103-131 (1990). 
28. Law, John: After method: Mess in social science research. Routledge, London \& New York (2004).

29. Löwgren, Jonas, \& Stolterman, Erik. Thoughtful interaction design: A design perspective on information technology. Mit Press (2004).

30. McNeil, Maureen, \& Roberts, Celia: Feminist science and technology studies. Theories and Methodologies in Postgraduate Feminist Research: researching differently, 29-42 (2011).

31. Melville, Nigel P. (2010). Information systems innovation for environmental sustainability. MIS quarterly, 34(1), 1-21 (2010).

32. Niemimaa, Marko. Sociomateriality and Information Systems Research: Quantum Radicals and Cartesian Conservatives. ACM SIGMIS Database: the DATABASE for Advances in Information Systems, 47(4), 45-59 (2016).

33. Orlikowski, Wanda J., \& Scott, Susan V.. Sociomateriality: challenging the separation of technology, work and organization. Academy of Management Annals, 2(1), 433-474 (2008).

34. Oudshoorn, Nelly, Rommes, Els, \& Stienstra, Marcelle. Configuring the user as everybody: Gender and design cultures in information and communication technologies. Science, Technology, \& Human Values, 29(1), 30-63 (2004).

35. Robinson, Laura, Cotten, Shelia R., Ono, Hiroshi, Quan-Haase, Anabel, Mesch, Gustavo, Chen, Wenhong, Schulz, Jeremy, Hale, Timoth, M. \& Stern, Michael J. Digital inequalities and why they matter. Information, Communication \& Society, 18(5), 569-582 (2015).

36. Salminen-Karlsson, Minna: Bringing Women into Computer Engineering: Curriculum Reform Processes at Two Institutes of Technology. Linkoping Studies in Education and Psychology Dissertations, No. 60 (1999).

37. Scott, Susan V., \& Orlikowski, Wanda J.: Entanglements in practice: Performing anonymity through social media. MISQ, 38(3): 873-893 (2014).

38. Sefyrin, Johanna, \& Mörtberg, Christina: "We do not talk about this": Problematical silences in eGovernment. Electronic Journal of e-Government, 7(3), 259-270 (2009).

39. Sefyrin, Johanna, Gidlund, Katarina L., Öberg, Karin D., \& Ekelin, Annelie: Representational practices in demands driven development of public sector. In International Conference on Electronic Government (pp. 200-211). Springer, Berlin, Heidelberg (2013).

40. Sommervold, Margaret M., \& van der Velden, Maja. Visions of Illness, Disease, and Sickness in Mobile Health Applications. Societies, 7(4), 28 (2017).

41. Suchman, Lucy. Human-machine reconfigurations: Plans and situated actions. Cambridge University Press (2007). 
42. Suchman, Lucy. Feminist STS and the Sciences of the Artificial. In Hackett, Edward, Amsterdamska, Olga, Lynch, Michael, and Wajcman, Judy (eds), The Handbook of Science and Technology Studie, 3rd edn. Cambridge, MA, MIT Press. Pp. 139-164 (2008).

43. Suchman, Lucy, Follis, Karolina, \& Weber, Jutta. Tracking and Targeting: Sociotechnologies of (In) security. Science, Technology \& Human Values, 2(6) 983-1002 (2017).

44. Swedish Government Official Reports 2015:65: Om Sverige i framtiden. En antologi om digitaliseringens möjligheter. [About Sweden in the future. An anthology about the possibilities with digitalization] (2015).

45. Sørensen, Carsten. The Curse of the Smart Machine? Digitalisation and the children of the mainframe. Scandinavian Journal of Information Systems, 28(2), 57-68 (2016).

46. Tsing, Anna L., Swanson, Heather A., Gan, Elaine \& Bubandt, Nils. Arts of Living on a Damaged Planet: Ghosts and Monsters of the Anthropocene. University of Minnesota Press (2017).

47. Van der Velden, M., \& Mörtberg, C.. Between need and desire: Exploring strategies for gendering design. Science, Technology, \& Human Values, 37(6), 663-683 (2012).

48. Wajcman, Judy: From women and technology to gendered technoscience. Information, Community and Society, 10(3), 287-298 (2007).

49. Wajcman, Judy: Feminist theories of technology. Cambridge journal of economics, 34(1), 143-152 (2010).

50. Walsham, Geoff: Are we making a better world with ICTs? Reflections on a future agenda for the IS field. Journal of Information Technology, 27(2), 87-93 (2012).

51. World Economic Forum: The Future of Jobs. Employment, Skills and Workforce Strategy for the Fourth Industrial Revolution. Global Challenge Insight Report (2016).

52. Åsberg, Cecilia, \& Lykke, Nina: Feminist technoscience studies. European Journal of Women's Studies, 17(4) 299-305 (2010). 